\title{
Successful interventional management of abdominal compartment syndrome caused by blunt liver injury with hemorrhagic diathesis
}

\author{
Hiroyuki Tokue*, Azusa Tokue and Yoshito Tsushima
}

\begin{abstract}
We report that a case of primary abdominal compartment syndrome (ACS), caused by blunt liver injury under the oral anticoagulation therapy, was successfully treated. Transcatheter arterial embolization (TAE) was initially selected, and the bleeding point of hepatic artery was embolized with N-Butyl Cyanoacylate (NBCA). Secondary, percutaneous catheter drainage (PCD) was performed for massive hemoperitoneum. There are some reports of ACS treated with TAE. However, combination treatment of TAE with NBCA and PCD for ACS has not been reported. Even low invasive interventional procedures may improve primary ACS if the patient has hemorrhagic diathesis or coagulopathy discouraging surgeon from laparotomy.
\end{abstract}

Keywords: Abdominal compartment syndrome, Transcatheter arterial embolization, N-butyl cyanoacylate

\section{Background}

Abdominal compartment syndrome (ACS) is a lifethreatening disorder, resulting when the consequent abdominal swelling or peritoneal fluid raises intraabdominal pressures (IAP) to supraphysiologic levels. ACS is defined as IAP above $20 \mathrm{mmHg}$ together with a new organ failure. The recommended treatment is initially medical while surgical decompression is indicated only when medical therapy fails [1-3]. However, it is hardly possible to achieve operation without any complications on ACS, and more difficult in the aged patients or hemorrhagic diathesis. We report that a case of primary ACS, caused by blunt liver injury under the oral anticoagulation therapy, was successfully treated with interventional techniques. Additionally, we reviewed the previous reports of ACS treated with transcatheter arterial embolization (TAE). It may be considered as an alternative to surgical intervention for an ACS.

\section{Case presentation}

A 71-year-old man was admitted to emergency unit for abdominal trauma due to traffic accident. His consciousness was unclear and shock index was 1.8 (blood

\footnotetext{
* Correspondence: tokue@s2.dion.ne.jp

Department of Diagnostic and Interventional Radiology, Gunma University Hospital, 3-39-22 Showa-machi, Maebashi, Gunma 371-8511, Japan
}

pressure, $70 / 39 \mathrm{~mm} \mathrm{Hg}$; pulse 125 beats/min). The electrocardiogram showed atrial fibrillation. His chest radiography showed markedly elevated diaphragms. The abdomen was distended, there were decreased sounds, and it was diffusely tender. Laboratory findings were as follows: hemoglobin $6.7 \mathrm{~g} / \mathrm{dL}$; international normalized ratio (INR) 3.2; because he was on the oral anticoagulation therapy for aterial fibrillation with warfarin and asprin. Arterial blood gas analysis revealed acute respiratory failure with a $\mathrm{pH}$ value of $7.344, \mathrm{PaO} 2$ of 61.5 torr, $\mathrm{PaCO} 2$ of 49.0 torr under $5 \mathrm{~L} / \mathrm{min}$ of oxygen supplementation by face mask. His urinary bladder pressure equal to intraabdominal pressures (IAP) was $26 \mathrm{cmH} 2 \mathrm{O}$. He became hemodynamically unstable with hypotension. Transfusion of fresh frozen plasma and packed red blood cells was followed by a fluid overload and vitamin K. And he was placed on ventilator. Ultrasonography detected a hemoperitoneum and liver laceration. Enhanced computed tomography (CT) showed that contrast material extravasation was in the hepatic hilum on arterial phase (Figure 1a), and an uncovered laceration extended over segments 1,4 and 8 of the liver with massive hemoperitoneum (Figure $1 \mathrm{~b}, \mathrm{c}$ ). There were associated several rib fractures in the right upper quadrant and mild right hemothorax. Finally, we diagnosed as primary ACS. However, surgeons hesitated to perform laparotomy because 

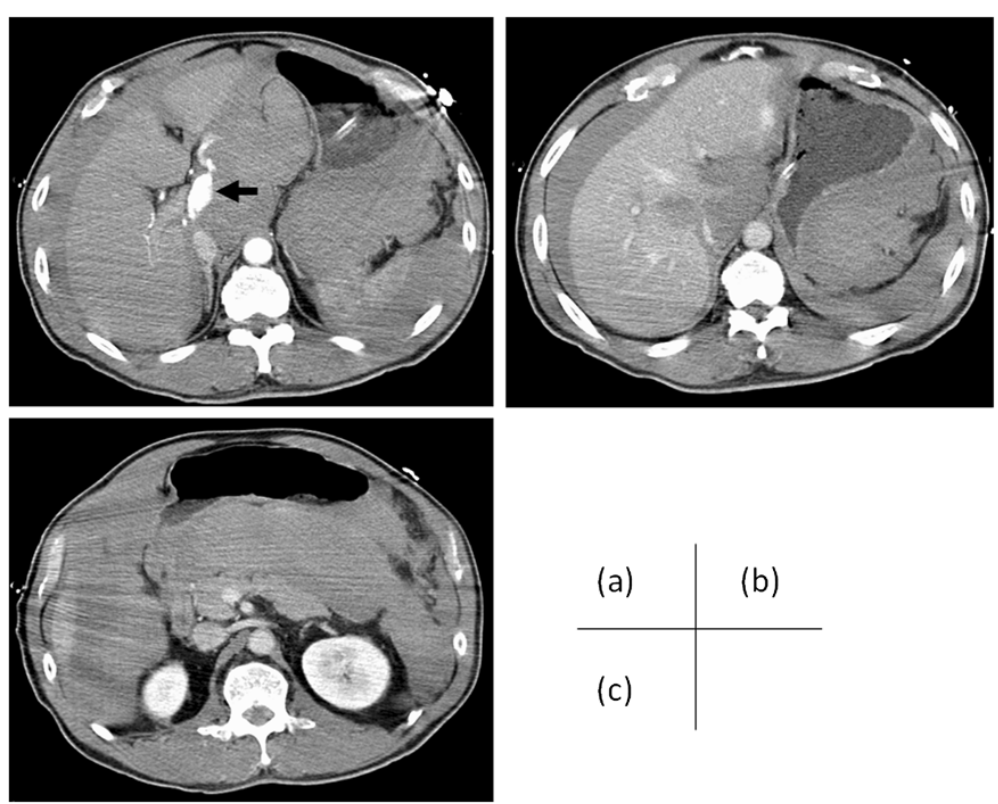

Figure 1 A 71-year-old man was admitted to emergency unit for abdominal trauma due to traffic accident. (a) CT showed that contrast material extravasation was in the hepatic hilum on arterial phase (arrow), and (b) an uncovered laceration extended over segments 1, 4 and 8 of the liver with massive hemoperitoneum. (c) CT scan at level at which left renal vein crosses aorta shows hemopritoneum. The ratio of anteroposterior-to-transverse diameter was equal to 1:0.76.

of his hemorrhagic diathesis, therefore TAE was initially selected. The celiac artery was quickly cannulated with a 5-Fr shephered hook catheter (Clinical Supply Co. Ltd., Gifu, Japan). Digtal subtraction angiography (DSA) of the celiac artery demonstrated the perforated left hepatic arterial branch with exravasation (Figure 2a). The right hepatic artery was replaced on the superior mesenteric artery without extravasation. 2.0-Fr coaxial microcatheter (Progreat, Terumo Corp., Tokyo) was advanced nearby the bleeding point of the left hepatic arterial branch using a 0.014-in. microguidwire (Transend EX, Boston Scientific Corp., Watertown, MA, USA) (Figure 2b). Embolizaion was performed using mixtures of $0.1 \mathrm{~mL}$ of N-Butyl Cyanoacylate (NBCA) and $0.5 \mathrm{~mL}$ of Lipiodol. After TAE, DSA did not demonstrate extravasation (Figure 2c,d) and the patient became hemodynamically stable. Under ultrasonographic guidance, we inserted a 10.2-Fr pigtail drainage catheter (Cook Inc., Bloomington, IN, USA) into the right paracolic gutter using Seldinger's technique. At the same time, IAP measured with the pigtail catheter was $30 \mathrm{cmH} 2 \mathrm{O}$. About $3.2 \mathrm{~L}$ of intra-abdominal blood was evacuated through the pigtail catheter for the next two hours. IAP dropped to $12 \mathrm{cmH} 2 \mathrm{O}$. He was discharged from the hospital without any major complications on 32 days after TAE.

\section{Discussion}

ACS is a life-threatening condition resulting when the consequent abdominal swelling or peritoneal fluid raises intraabdominal pressures (IAP) to supraphysiologic levels, in massive abdominal hemorrhage, ascites, pancreatitis, ileus, as above [1-3]. At the World Congress of ACS in 2004, the World Society of Abdominal Compartment Syndrome, ACS is defined as an IAP above $20 \mathrm{mmHg}$ with evidence of organ dysfunction/failure $[4,5]$. In our case, respiratory failure had been revealed. Increased IAP causes venous stasis and arterial malperfusion of all intra-and extra-abdominal organs, resulting in ischemia, hypoxia and necrosis. In parallel, respiratory, cardiocirculatory, renal, intestinal and cerebral decompensation can be seen.

Recently, ACS is divided to three types $[4,5]$. Primary (postinjury) ACS, applied to our case, is a condition associated with injury or disease in the abdomino-pelvic region that frequently requires early surgical or interventional radiological intervention. Total body shock and subsequent reperfusion with intestinal edema and a tightly packed and closed abdomen increase abdominal pressure.

Secondary ACS refers to conditions that do not originate from the abdomino-pelvic region. The typical injury patterns are penetrating heart, major vessel, or extremity vascular trauma associated with profound shock and subsequent massive resuscitation resulting in whole-body ischemia or reperfusion injury. Recurrent ACS represents a redevelopment of ACS symptoms following resolution of an earlier episode of either prmary or secondary ACS. 

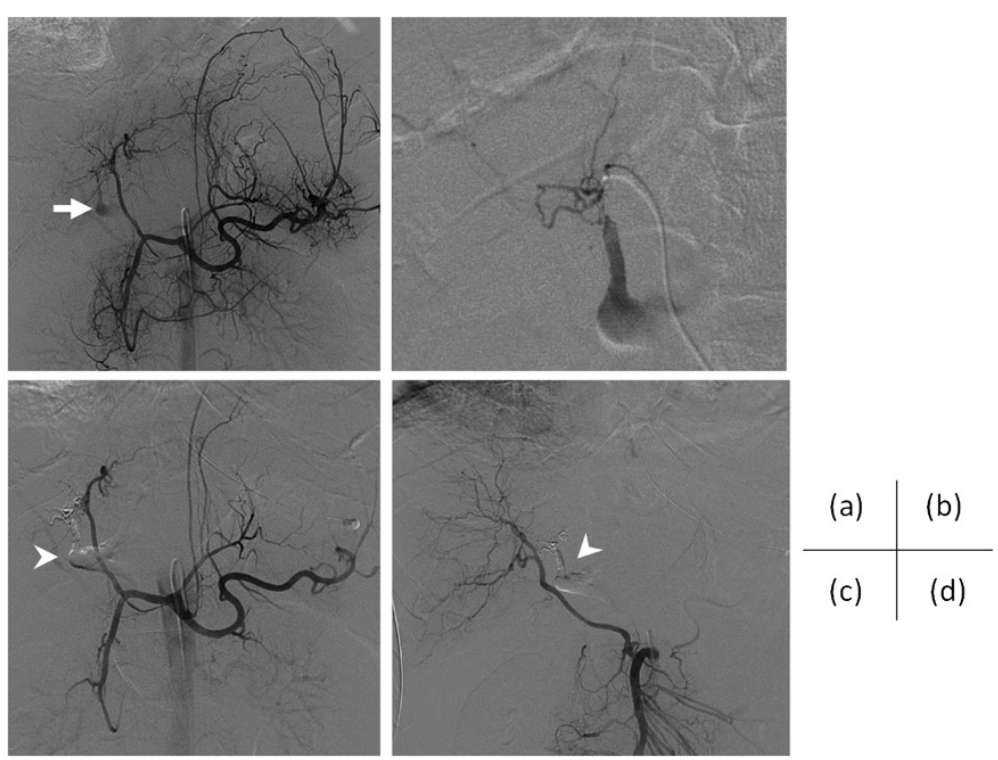

Figure 2 The images of digital subtraction angiography (DSA). The right hepatic artery arose from the superior mesenteric artery (SMA). (a) Celiac arteriography demonstrated contrast material extravasation from the left hepatic arterial branch (arrow). (b) Super selective DSA was confirmed leakage of the left hepatic aiterial branch. (c) After transcatheter arterial embolization, DSA of the celiac artery and (d) SMA did not demonstrate extravasation. Filled N-Butyl Cyanoacylate (NBCA) and Lipiodol were seen (arrowheads).

Radiologically, Pickhardt et al. [1] described increased ratio of anteroposterior-to-transverse abdominal diameter over 0.8 on CT. However, Zissin [6], reported that valuable peritoneal diseases may increase this ratio without ACS, and Laffargue et al. [7] revealed that the ratio of anteroposterior-to-transverse abdominal diameter was under 0.8 in primary ACS. In our case, the ratio of anteroposterior-to-transverse diameter on CT was equal to 1:0.76 (Figure 1c).

We suppose that ACS is not always completed on that time when the CT is performed to the patient with active intraabdominal hemorrhage. Therefore, we should make a diagnosis of ACS as soon as possible; the most useful and simple examination is measurement of IAP, substituted by urinary bladder pressure.

ACS is generally required surgical decompression, whereas unaccustomed surgeons hesitate to perform laparotomy, because of perioperative high mortality rate, long staying at the intensive care unit, reoperation, and late complications including incisional hernia, gastrointestinal and pancreatic fistulas, abscess, polyneuropathy, psychic disorders, as above [1]. Additionally, our patient was on hemorrhagic diathesis with the oral anticoagulation therapy for atrial fibrillation, and attended with suspicious

Table 1 The characteristics of the reported cases of abdominal compartment syndrome treated with transcatheter arterial embolization

\begin{tabular}{|c|c|c|c|c|c|}
\hline Author & $\mathbf{N}$ & Clinical presentation & Embolized artery & Embolic material & Subsequent treatment \\
\hline Letoublon [9] & 14 & Blunt hepatic trauma & Hepatic artery & NS & $\begin{array}{l}\text { Decompressive laparotomy or } \\
\text { laparoscopy }\end{array}$ \\
\hline Won [10] & 1 & Retroperitoneal hemorrhage & Internal iliac artery & Gelatin sponge, coil, lipiodol & Decompressive laparotomy \\
\hline Pena [11] & 1 & Splenomegaly & Splenic artery & PVA & Nothing \\
\hline \multirow[t]{2}{*}{ Monnin [12] } & 7 & Blunt hepatic trauma & Hepatic artery & Gelatin sponge, coil & Decompressive laparotomy \\
\hline & & & & Trisacryl gelatin microsphere & \\
\hline Hagiwara [13] & 1 & Pelvic flactures & Super gluteal artery & Gelatin sponge & $\begin{array}{l}\text { Repeat TAE, decompressive } \\
\text { laparotomy }\end{array}$ \\
\hline \multirow[t]{2}{*}{ Isokangas [14] } & 5 & Retroperitoneal hemorrhage & Lumbar artery $(\mathrm{N}=4)$ & Gelatin sponge, PVA, coil & Surgical decompreesion $(N=4)$ \\
\hline & & & Medial rectal artery $(\mathrm{N}=1)$ & & US guided drainage $(\mathrm{N}=1)$ \\
\hline Tokue (present) & 1 & Blunt hepatic trauma & Hepatic artery & NBCA, lipiodol & US guided drainage \\
\hline
\end{tabular}

$\mathrm{N}$ : number of patients, NS: not shown, PVA: polyvinyl alcohol, NBCA: N-Butyl Cyanoacylate, US: ultrasonography. 
disseminated intravascular coagulation due to massive hemorrhage. But it wcxxas expected that the major vascular leakage was only in the hepatic arterial branch without any bowel perforation on the contrast-enhanced CT, so we performed interventional procedure. NBCA was the most appropriate embolic agent of TAE for our case with hemorrhagic diathesis, because it does not depend on the coagulation process for its therapeutic effect [8].
There are some reports of ACS treated with TAE [9]. However, combination treatment of TAE with NBCA and percutaneous catheter drainage (PCD) for ACS has not been reported (Table 1). We suggest that initial hemostasis by transcatheter arterial embolization is a safe, effective treatment method for abdominal compartment syndrome with active arterial bleeding in a patient undergoing anticoagulation.

Table 2 Characteristics of the randomized controlled trials on IAP, IAH, and ACS

\begin{tabular}{|c|c|c|c|c|c|}
\hline Author & $\mathbf{N}$ & Study population & Intervention & Control & Main conclusion \\
\hline \multirow[t]{2}{*}{ Celik [15] } & \multirow[t]{2}{*}{100} & Patients undergoing elective & 5 different IAP levels; 8, 10, & \multirow[t]{2}{*}{ NA } & No effect of IAP levels on gastric \\
\hline & & Laparoscopic cholecystectomy & 12,14, and $16 \mathrm{~mm} \mathrm{Hg}$ & & intramucosal pH \\
\hline Basgul [16] & 22 & $\begin{array}{l}\text { Patients undergoing elective } \\
\text { laparoscopic cholecystectomy }\end{array}$ & Low IAP level (10 mm Hg) & $\begin{array}{l}\text { High IAP level } \\
(14 Y 15 \mathrm{~mm} \mathrm{Hg})\end{array}$ & $\begin{array}{l}\text { Less depression of immune } \\
\text { function (expressed as interleukin } \\
2 \text { and 6) in the low IAP group }\end{array}$ \\
\hline O'Mara [17] & 31 & $\begin{array}{l}\text { Burn patients ( }>25 \% \text { TBS with } \\
\text { inhalation injury or }>40 \% \\
\text { TBS without) }\end{array}$ & Plasma resuscitation & Crystalloid resuscitation & $\begin{array}{l}\text { Less increase in IAP and less } \\
\text { volume requirement in plasma- } \\
\text { resuscitated patients }\end{array}$ \\
\hline Sun [18] & 110 & $\begin{array}{l}\text { Severe acute pancreatitis } \\
\text { patients }\end{array}$ & $\begin{array}{l}\text { Routine conservative treatment } \\
\text { combined with indwelling } \\
\text { catheter drainage }\end{array}$ & $\begin{array}{l}\text { Routine conservative } \\
\text { treatment }\end{array}$ & $\begin{array}{l}\text { Lower mortality, lower APACHE II } \\
\text { scores after } 5 \mathrm{~d} \text { and shorter } \\
\text { hospitalization times in } \\
\text { intervention group }\end{array}$ \\
\hline Bee [19] & 51 & $\begin{array}{l}\text { Patients undergoing emergency } \\
\text { laparotomy requiring temporary } \\
\text { abdominal closure }\end{array}$ & Vacuum-assisted closure & Mesh closure & $\begin{array}{l}\text { No signification differences in } \\
\text { delayed fascial closure or fistula } \\
\text { rate }\end{array}$ \\
\hline Karagulle [20] & 45 & $\begin{array}{l}\text { Patients undergoing elective } \\
\text { laparoscopic cholecystectomy }\end{array}$ & $\begin{array}{l}3 \text { different IAP levels; 8, 12, } \\
\text { and } 15 \mathrm{~mm} \mathrm{Hg}\end{array}$ & NA & $\begin{array}{l}\text { Similar effects on pulmonary } \\
\text { function test results }\end{array}$ \\
\hline Zhang [21] & 80 & Severe acute pancreatitis patients & $\begin{array}{l}\text { Da-Cheng-Qi decoction } \\
\text { enema and sodium sulphate } \\
\text { orally }\end{array}$ & Normal saline enema & $\begin{array}{l}\text { Lower IAP levels in intervention } \\
\text { group }\end{array}$ \\
\hline Ekici [22] & 52 & $\begin{array}{l}\text { Patients undergoing elective } \\
\text { laparoscopic cholecystectomy }\end{array}$ & Low IAP level (7 mm Hg) & $\begin{array}{l}\text { High IAP level } \\
(15 \mathrm{~mm} \mathrm{Hg})\end{array}$ & $\begin{array}{l}\text { More pronounced effect of high } \\
\text { IAP on QT dispersion }\end{array}$ \\
\hline Joshipura [23] & 26 & $\begin{array}{l}\text { Patients undergoing elective } \\
\text { laparoscopic cholecystectomy }\end{array}$ & Low IAP level $(8 \mathrm{~mm} \mathrm{Hg})$ & $\begin{array}{l}\text { High IAP level } \\
(12 \mathrm{~mm} \mathrm{Hg})\end{array}$ & $\begin{array}{l}\text { Decrease in postoperative pain } \\
\text { and hospital stay, and } \\
\text { preservation of lung function in } \\
\text { low pressure level group }\end{array}$ \\
\hline Mao [24] & 76 & $\begin{array}{l}\text { Severe acute pancreatitis } \\
\text { patients }\end{array}$ & Controlled fluid resuscitation & Rapid fluid resuscitation & $\begin{array}{l}\text { Lower incidence of ACS in } \\
\text { controlled fluid resuscitation } \\
\text { group (i.a.) }\end{array}$ \\
\hline Yang [25] & 120 & $\begin{array}{l}\text { Severe acute pancreatitis } \\
\text { patients }\end{array}$ & $\begin{array}{l}\text { Colloid plus crystalloid } \\
\text { resuscitation }\end{array}$ & Crystalloid resuscitation & $\begin{array}{l}\text { Decline of IAP was significant } \\
\text { higher in crystalloid plus colloid } \\
\text { group }\end{array}$ \\
\hline Celik [26] & 60 & $\begin{array}{l}\text { Patients undergoing elective } \\
\text { laparoscopic cholecystectomy }\end{array}$ & $\begin{array}{l}3 \text { different IAP levels; 8, } 12 \\
\text { and } 14 \text { mm Hg }\end{array}$ & NA & $\begin{array}{l}\text { No effect of IAP level on } \\
\text { postoperative pain }\end{array}$ \\
\hline \multirow[t]{2}{*}{ Chen [27] } & \multirow[t]{2}{*}{60} & \multirow[t]{2}{*}{$\begin{array}{l}\text { ICU patients with multiorgan } \\
\text { failure }\end{array}$} & Tongfu Granule & \multirow[t]{2}{*}{ Placebo } & \multirow[t]{2}{*}{$\begin{array}{l}\text { Decreased IAP in intervention } \\
\text { group }\end{array}$} \\
\hline & & & (Traditional Chinese medicines) & & \\
\hline Agarwal [28] & 190 & $\begin{array}{l}\text { Patients undergoing emergency } \\
\text { laparotomy }\end{array}$ & Reinforced tension line sutures & Continuous suturing & $\begin{array}{l}\text { No difference in IAP but increased } \\
\text { incidence of fascial dehiscence in } \\
\text { continuous suture group }\end{array}$ \\
\hline Du [29] & 41 & $\begin{array}{l}\text { Severe acute pancreatitis } \\
\text { patients }\end{array}$ & Hydroxyethyl starch resuscitation & $\begin{array}{l}\text { Ringer's lactate } \\
\text { resuscitation }\end{array}$ & $\begin{array}{l}\text { Lower incidence of IAH and } \\
\text { reduced use of mechanical } \\
\text { ventilation in intervention group }\end{array}$ \\
\hline Topal [30] & 60 & $\begin{array}{l}\text { Patients undergoing elective } \\
\text { laparoscopic cholecystectomy }\end{array}$ & $\begin{array}{l}3 \text { different IAP levels; 10, 13, } \\
\text { and } 16 \mathrm{~mm} \mathrm{Hg}\end{array}$ & NA & $\begin{array}{l}\text { No differences on } \\
\text { thromboelastography }\end{array}$ \\
\hline
\end{tabular}

$\mathrm{N}$ : number of patients, APACHE: Acute Physiology And Chronic Health Evaluation, NA: not applicable/available; TBS: Total body surface area, IAP: intra-abdominal pressure, IAH: intra-abdominal hypertension, ACS: abdominal compartment syndrome. 
The decompression is simultaneously essential to hemostasis for the treatment of primary ACS. There are some randomized controlled trials for ACS (Table 2) [31]. However, there have been no randomized controlled trials about which is better, PCD or decompressive laparotomy. PCD is easy and minimal invasive procedure compared with surgical decompression, and allows us to measure IAP. But it is not appropriate to perform catheter drainage for the patients with widespread peritonitis or bowel injury. When a heavy clot burden cannot be drained satisfactorily via catheter, we should transfer to decompressive laparotomy.

\section{Conclusions}

In summary, we described the case of primary ACS caused by blunt liver injury. Interventional procedures may improve primary ACS if the patient has hemorrhagic diathesis or coagulopathy discouraging surgeon from laparotomy, limited vascular injury, and no obvious peritonitis.

\section{Consent}

Written informed consent was obtained from the patient for publication of this Case report and any accompanying images. A copy of the written consent is available for review by the Editor of this journal.

\section{Competing interests}

The authors declare that they have no competing interests.

\section{Authors' contributions}

All authors read and approved the final manuscript.

Received: 20 December 2013 Accepted: 18 March 2014

Published: 22 March 2014

\section{References}

1. Pickhardt PJ, Shimony JS, Heiken JP, Buchman TG, Fisher AJ: The abdominal compartment syndrome: CT findings. Am J Roentgenol 1999, 173:575-579.

2. Sugerman HJ, Bloomfield GL, Saggi BW: Multisystem organ failure secondary to increased intra-abdominal pressure. Infection 1999, 27:61-66.

3. Burch JM, Moore EE, Moore FA, Francoise R: The abdominal compartment syndrome. Surg Clin North Am 1999, 76:833-842.

4. Kirkpatrick AW, Roberts DJ, De Waele J, Jaeschke R, Malbrain ML, De Keulenaer B, Duchesne J, Bjorck M, Leppaniemi A, Ejike JC, Sugrue M, Cheatham M, Ivatury R, Ball CG, Reintam Blaser A, Regli A, Balogh Z, D'Amours S, Debergh D, Kaplan M, Kimball E, Olvera C: Pediatric Guidelines Sub-Committee for the World Society of the Abdominal Compartment Syndrome. Intra-abdominal hypertension and the abdominal compartment syndrome: updated consensus definitions and clinical practice guidelines from the World Society of the Abdominal Compartment Syndrome. Intensive Care Med 2013, 39:1190-206.

5. Zissin R: The significance of a positive round belly sign on CT. Am J Roentgenol 2000, 175:267.

6. Laffargue $G$, Taourel $P$, Saguintaah $M$, Lesnik $A: C T$ diagnosis of abdominal compartment syndrome. Am J Roentgenol 2002, 178:771-772.

7. Yonemitsu T, Kawai N, Sato M, Sonomura T, Takasaka I, Nakai M, Minamiguchi H, Sahara S, Iwasaki Y, Naka T, Shinozaki M: Comparison of hemostatic durability between $\mathrm{N}$-butyl cyanoacrylate and gelatin sponge particles in transcatheter arterial embolization for acute arterial hemorrhage in a coagulopathic condition in a swine model. Cardiovasc Intervent Radiol 2010, 33:1192-1197.
8. Vikrama KS, Shyamkumar NK, Vinu M, Joseph P, Vyas F, Venkatramani S: Percutaneous catheter drainage in the treatment of abdominal compartment syndrome. Can J Surg 2009, 52:E19-20.

9. Letoublon C, Morra I, Chen Y, Monnin V, Voirin D, Arvieux C: Hepatic arterial embolization in the management of blunt hepatic trauma: indications and complications. J Trauma 2011, 70:1032-1036.

10. Won DY, Kim SD, Park SC, Moon IS, Kim Jl: Abdominal compartment syndrome due to spontaneous retroperitoneal hemorrhage in a patient undergoing anticoagulation. Yonsei Med J 2011, 52:358-361.

11. Pena AH, Kaplan P, Ganesh J, Clevac E, Marie CA: Partial splenic embolization in a child with Gaucher disease, massive splenomegaly and severe thrombocytopenia. Pediatr Radiol 2009, 39:1006-1009.

12. Monnin V, Sengel C, Thony F, Bricault I, Voirin D, Letoublon C, Broux C, Ferretti G: Place of arterial embolization in severe blunt hepatic trauma: a multidisciplinary approach. Cardiovasc Intervent Radiol 2008, 31:875-882.

13. Hagiwara A, Fukushima $H$, Inoue T, Murata A, Shimazaki S: Brain death due to abdominal compartment syndrome caused by massive venous bleeding in a patient with a stable pelvic fracture: report of a case. Surg Today 2004, 34:82-85.

14. Isokangas JM, Perälä JM: Endovascular embolization of spontaneous retroperitoneal hemorrhage secondary to anticoagulant treatment. Cardiovasc Intervent Radiol 2004, 27:607-611

15. Celik V, Salihoglu Z, Demiroluk S, Unal E, Yavuz N, Karaca S, Carkman S, Demiroluk O: Effect of intra-abdominal pressure level on gastric intramucosal pH during pneumoperitoneum. Surg Laparosc Endosc Percutan Tech 2004, 14:247-249.

16. Basgul E, Bahadir B, Celiker V, Karagoz AH, Hamaloglu E, Aypar U: Effects of low and high intra-abdominal pressure on immune response in laparoscopic cholecystectomy. Saudi Med J 2004, 25:1888-1891.

17. O'Mara MS, Slater H, Goldfarb IW, Caushaj PF: A prospective, randomized evaluation of intra-abdominal pressures with crystalloid and colloid resuscitation in burn patients. J Trauma 2005, 58:1011-1018.

18. Sun ZX, Huang HR, Zhou H: Indwelling catheter and conservative measures in the treatment of abdominal compartment syndrome in fulminant acute pancreatitis. World J Gastroenterol 2006, 12:5068-5070.

19. Bee TK, Croce MA, Magnotti LJ, Zarzaur BL, Maish GO 3rd, Minard G, Schroeppel TJ, Fabian TC: Temporary abdominal closure techniques: a prospective randomized trial comparing polyglactin 910 mesh and vacuum-assisted closure. J Trauma 2008, 65:337-342.

20. Karagulle E, Turk E, Dogan R, Ekici Z, Dogan R, Moray G: The effects of different abdominal pressures on pulmonary function test results in laparoscopic cholecystectomy. Surg Laparosc Endosc Percutan Tech 2008, 18:329-333.

21. Zhang MJ, Zhang GL, Yuan WB, Ni J, Huang LF: Treatment of abdominal compartment syndrome in severe acute pancreatitis patients with traditional Chinese medicine. World J Gastroenterol 2008, 14:3574-3578.

22. Ekici $Y$, Bozbas H, Karakayali F, Salman E, Moray G, Karakayali H, Haberal M Effect of different intra-abdominal pressure levels on QT dispersion in patients undergoing laparoscopic cholecystectomy. Surg Endosc 2009, 23:2543-2549.

23. Joshipura VP, Haribhakti SP, Patel NR, Naik RP, Soni HN, Patel B, Bhavsar MS, Narwaria MB, Thakker R: A prospective randomized, controlled study comparing low pressure versus high pressure pneumoperitoneum during laparoscopic cholecystectomy. Surg Laparosc Endosc Percutan Tech 2009, 19:234-240.

24. Mao EQ, Tang YQ, Fei J, Qin S, Wu J, Li L, Min D, Zhang SD: Fluid therapy for severe acute pancreatitis in acute response stage. Chin Med J 2009, 122:169-173.

25. Yang ZY, Wang CY, Jiang HC, Sun B, Zhang ZD, Hu WM, Ou JR, Hou BH: Effects of early goal-directed fluid therapy on intra-abdominal hypertension and multiple organ dysfunction in patients with severe acute pancreatitis [in Chinese]. ZhonghuaWai Ke Za Zhi 2009, 47:1450-1454.

26. Celik AS, Frat N, Celebi F, Guzey D, Kaplan R, Birol S, Memmi N: Laparoscopic cholecystectomy and postoperative pain: is it affected by intra-abdominal pressure? Surg Laparosc Endosc Percutan Tech 2010, 20:220-222.

27. Chen X, Li A, Zhang SW: Effects of Tongfu Granule on intestinal dysfunction in patients with multiple organ dysfunction syndrome [in Chinese]. Zhongguo Zhong Xi Yi Jie He Za Zhi 2010, 30:810-813. 
28. Agarwal A, Hossain Z, Agarwal A, Das A, Chakraborty S, Mitra N, Gupta M, Ray U: Reinforced tension line suture closure after midline laparotomy in emergency surgery. Trop Doct 2011, 41:193-196.

29. Du XJ, Hu WM, Xia Q, Huang ZW, Chen GY, Jin XD, Xue P, Lu HM, Ke NW, Zhang ZD, Li QS: Hydroxyethyl starch resuscitation reduces the risk of intra-abdominal hypertension in severe acute pancreatitis. Pancreas 2011, 40:1220-1225.

30. Topal A, Celik JB, Tekin A, Yüceaktaş A, Otelcioğlu S: The effects of 3 different intra-abdominal pressures on the thromboelastographic profile during laparoscopic cholecystectomy. Surg Laparosc Endosc Percutan Tech 2011, 21:434-438.

31. Atema JJ, van Buijtenen JM, Lamme B, Boermeester MA: Clinical studies on intra-abdominal hypertension and abdominal compartment syndrome. J Trauma Acute Care Surg 2014, 76:234-240.

doi:10.1186/1749-7922-9-20

Cite this article as: Tokue et al: Successful interventional management of abdominal compartment syndrome caused by blunt liver injury with hemorrhagic diathesis. World Journal of Emergency Surgery 2014 9:20.

\section{Submit your next manuscript to BioMed Central and take full advantage of:}

- Convenient online submission

- Thorough peer review

- No space constraints or color figure charges

- Immediate publication on acceptance

- Inclusion in PubMed, CAS, Scopus and Google Scholar

- Research which is freely available for redistribution 